\title{
PENGARUH KELENGKAPAN PRODUK, HARGA, PROMOSI DAN KEPUASAN PELANGGAN TERHADAP LOYALITAS PELANGGAN DI RAMAYANA PADANG
}

\author{
Denis Triana Muriza, Hayu Yolanda Utami, Stevani \\ Program Studi Pendidikan Ekonomi STKIP PGRI Sumatera Barat \\ denistriana03@gmail.com
}

\begin{abstract}
The aim of this study was to find out the effect of product completeness price, promotion and customer satisfaction toward customer loyalty in Ramayana Padang. this research was a quantitative research with descriptive and associative methods. The population of this research were all of members in ramayana Padang who active purchases at Ramayana which a sample of 96 people. Technique of data analysis was descriptive and inductive analysis using multiple linear regression analysis. The results showed that: the completeness of the product $\left(\mathrm{X}_{1}\right)$, price $\left(\mathrm{X}_{2}\right)$, promotion $\left(\mathrm{X}_{3}\right)$ and customer satisfaction $(\mathrm{X} 4)$ had significant effect toward customer loyalty $(Y)$, where $F_{\text {counted }}(220,733)>F_{\text {table }}$ $(2,47)$. Based on the research results, it is expected that the company leadership for 1) continue to pay attention to the completeness of the types of products provided to customers, 2) the price offered must be able to reach all of groups, 3) promotional activities that have attracted the attention of these customers so that they are maintained and try to increase the frequency in the media, 4) maintaining the good name of the compeny and paying attention to all future customer needs.

Keywords: Product Completeness, Price, Promotion,Customer Satisfaction and Customer Loyalty.

\section{PENDAHULUAN}

Pemasaran adalah salah satu kegiatan pokok yang perlu dilakukan oleh perusahaan baik itu perusahaan barang atau jasa dalam upaya untuk mempertahankan kelangsungan hidup usahanya. Hal tersebut disebabkan karena pemasaran merupakan salah satu kegiatan

perusahaan, dimana secara langsung berhubungan dengan konsumen. Maka kegiatan pemasaran dapat diartikan sebagai kegiatan manusia yang berlangsung dalam kaitannya dengan pasar.

Perkembangan perekonomian Indonesia yang dinamis ini juga terus menghiasi usaha di Sumatera Barat
\end{abstract}


khususnya Kota Padang. Upayaupaya untuk memuaskan kebutuhan konsumen dilakukan oleh setiap perusahaan dengan strategi dan cara dengan harapan konsumen merasa puas dan akan melakukan pembelian ulang sebagai timbal baliknya.

Tabel 1. Daftar Pasar Modern Di Kota Padang

\begin{tabular}{clcl}
\hline No & \multicolumn{1}{c}{ Ritel } & Tahun Operasi & \multicolumn{1}{c}{ Alamat } \\
\hline 1 & $\begin{array}{l}\text { Plaza Andalas } \\
\text { (Ramayana) }\end{array}$ & 2008 & Jl. Diponegoro, Belakang Tangsi \\
2 & $\begin{array}{l}\text { Basko Grand Mall } \\
\text { (Matahari) }\end{array}$ & 2010 & Jl. Prof. Dr. Hamka No. 2A \\
3 & Rocky Plaza (Suzuya) & 2011 & Jl. Permindo Kel No. 40 \\
4 & SPR Plaza (Matahari) & 2010 & Jl. Moh. Yani No. 91 \\
5 & SJS Plaza & 2013 & Jl. Jhoni Anwar No.1 \\
6 & Damar Plaza & 2013 & Jl. Damar, Olo \\
7 & Transmart & 2017 & Jl. Khatib Sulaiman No. 85 \\
\hline
\end{tabular}

Sumber: Observasi Lapangan, Tahun 2020

Pengalaman yang diperoleh

konsumen dari suatu produk atau jasa yang baik akan menimbulkan kesan positif yang menunjukkan bahwa konsumen mendapatkan apa yang diinginkannya, sehingga konsumen akan loyal terhadap barang atau jasa yang digunakannya. Perusahaan tidak dapat mengabaikan pendapat atau masukan dari pelanggan karena keberadaan pelanggan sendiri mempunyai pengaruh pada pencapaian tujuan akhir perusahaan. Dimana salah satu faktor yang menentukan tingkat
Apabila seorang konsumen telah berubah menjadi pelanggan yang loyal karena kepuasannya terpenuhi, maka konsumen tersebut tidak akan beralih ke produk atau jasa perusahaan lain sejenis. keberhasilan perusahaan produk atau jasa adalah kemampuan perusahaan

dalam memberikan pelayanan yang berkualitas kepada pelanggan. Seringkali perusahaan masih berfokus hanya pada pencapaian produktivitas dan profitabilitas dengan mengabaikan aspek kepuasan yang menimbulkan loyalitas pelanggan.

Loyalitas menurut Simamora dalam Sari (2012: 8) merupakan perilaku pelanggan untuk dengan pasti membeli apa dan kepada siapa untuk mempengaruhi kebutuhannya. 
Dengan kata lain perilaku pembeliannya tidak dihabiskan dengan mengacak (non random) beberapa unit keputusan karena pelanggan yang loyal mempunyai kecenderungan yang pasti dalam membeli.

Loyalitas pelanggan merupakan tujuan inti yang diupayakan pemasar dalam mempertahankan dan meningkatkan pelanggan. Hal ini dikarenakan dengan loyalitas yang sesuai dengan yang diharapkan maka dipastikan akan memberikan keuntungan di saat ini dan masa yang akan datang. Dalam jangka panjang, loyalitas pelanggan menjadi tujuan bagi perencanaan strategik sebagai dasar pengembangan keunggulan yang kompetitif yang berkelanjutan (Hasan dalam Utami (2014: 65).

Kelengkapan jenis produk merupakan salah satu faktor yang mempengaruhi loyalitas pelanggan serta cara untuk menarik konsumen/pelanggan yang dimiliki oleh Ramayana. Menurut Ma'ruf dalam Herlina (2018: 110) menyatakan bahwa kelengkapan produk adalah kegiatan pengadaan barang-barang yang sesuai dengan bisnis yang dijalani toko (produk berbasis makanan, pakaian, barang kebutuhan rumah, produk umum dan lain-lain atau kombinasi) untuk disediakan dalam toko pada jumlah, waktu dan harga yang sesuai untuk mencapai sasaran toko atau perusahaan ritel.

Pada dasarnya masyarakat secara umum akan beralih ke perusahaan lain jika harga suatu barang atau jasa yang ditawarkan mengalami peningkatan yang cukup drastis. Menurut Kotler dan Amstrong dalam Marlina (2017: 7) adalah sejumlah uang yang ditukarkan untuk sebuah produk atau jasa. Harga merupakan suatu masalah jika perusahaan akan menetapkan harga pertama kalinya, karena harga akan mempengaruhi pendapatan total dan biaya. Harga merupakan faktor utama dalam penentuan posisi dan harus diputuskan sesuai dengan pasar sasaran, bauran ragam produk dan pelayanan, serta persaingan (Kotler dan Amstrong dalam Pongoh (2013: $88)$. 
Vol. 1 No. 2 (Mei 2021) (294-304)

Promosi juga merupakan hal terpenting karena promosi akan membawa citra perusahaan. Promosi merupakan arus informasi atau persuasi satu arah yang dibuat untuk mengarahkan komunikasi persuasif pada pembelian sasaran dan masyarakat melalui media-media yang disebut dengan media massa. Menurut Levy dalam Soraya (2015:12) mengemukakan promosi adalah komunikasi yang dilakukan oleh pemasar untuk menginformasikan, membujuk dan mengingatkan pembeli potensial akan produk, atau jasa untuk mempengaruhi opini pembeli dan memperoleh respon dari pembeli. Sedangkan menurut sutojo dalam Amanah (2018: 223) mengemukakan bahwa promosi adalah upaya memberi tahu dan mengingatkan konsumen akan keberadaan barang atau jasa tersebut dipasar dan manfaatnya.

Kotler and Keller dalam Suparmi (2018:105) menyatakan bahwa kepuasan pelanggan adalah perasaan senang atau kekecewaan seseorang setelah membandingkan kinerja atau hasil yang dirasakan dibandingkan dengan harapannya. Menurut Kotler dalam Tahuman (2016:44) kepuasan adalah perasaan kesenangan atau kekecewaan dari hasil membandingkan perfoma produk yang diterima dalam hubungannya dalam perkiraannya. Sedangkan menurut Park dalam Normasari (2013:3) kepuasan pelanggan merupakan suatu perasaan konsumen sebagai responden terhadap produk barang atau jasa yang telah dikonsumsi.

Berdasarkan uraian di atas, penulis tertarik untuk meneliti lebih jauh mengenai "Pengaruh Kelengkapan Produk, Harga, Promosi dan Kepuasan Pelanggan Terhadap Loyalitas Pelanggan di Ramayana Padang.”

\section{METODE PENELITIAN}

Metode yang digunakan dalam penelitian ini adalah metode deskriptif dan asosiatif. Menurut Sugiyono (2012: 35) deskriptif adalah suatu masalah yang berkenaan dengan pertanyaan terhadap keberadaan variabel mandiri, baik 
hanya pada satu variabel atau lebih (variabel yang berdiri sendiri).

Sedangkan assosiatif adalah suatu masalah penelitian yang bersifat menanyakan hubungan antara dua variabel atau lebih Sugiyono (2012: 36). Penelitian ini dilaksanakan di Ramayana Plaza Andalas, Jalan Diponegoro, Belakang Tangsi, Olo, Kecamatan Padang Barat, Kota Padang, Sumatera Barat. Dilaksanakan pada bulan Januari 2021. Jumlah sampel yang ditetapkan dalam penelitian ini adalah sebanyak 96 responden dengan menggunakan teknik pengambilan sampel purposive sampling.

Dalam penelitian ini teknik analisis data yang digunakan adalah analisis deskriptif, uji kelayakan model, uji asumsi klasik, analisis regresi linear berganda, koefisien determinasi dan uji hipotesis.

\section{HASIL DAN PEMBAHASAN}

Berdasarkan penelitian yang telah dilakukan di Ramayana Padang, penulis mendapatkan hasil dari angket yang telah dibagikan kepada pelangan dengan hasil sebagai berikut:

Tabel 2. Hasil Regresi Linear Berganda

\begin{tabular}{|c|c|c|c|c|c|c|}
\hline \multirow{2}{*}{\multicolumn{2}{|c|}{ Model }} & \multicolumn{2}{|c|}{$\begin{array}{l}\text { Unstandardized } \\
\text { Coefficients }\end{array}$} & \multirow{2}{*}{$\begin{array}{c}\text { Standardized } \\
\text { Coefficients } \\
\text { Beta }\end{array}$} & \multirow[t]{2}{*}{$\mathrm{T}$} & \multirow[t]{2}{*}{ Sig. } \\
\hline & & B & Std. Error & & & \\
\hline \multirow{5}{*}{1} & (Constant) & -1.549 & 2.172 & & -.713 & .478 \\
\hline & Kelengkapan Produk & 1.517 & .147 & .746 & 10.343 & .000 \\
\hline & Harga & .001 & .071 & .000 & .011 & .991 \\
\hline & Promosi & .039 & .054 & .030 & .715 & .477 \\
\hline & Kepuasan Pelanggan & .304 & .108 & .205 & 2.812 & .006 \\
\hline
\end{tabular}

Sumber: Olahan Data Primer Tahun 2021

Berdasarkan hasil yang terdapat pada tabel diatas, maka dapat dirumuskan persamaan regresi linear berganda sebagai berikut:

$$
\begin{aligned}
Y= & a+b_{1} X_{1}+b_{2} X_{2}+b_{3} X_{3}+b_{4} X_{4} \\
Y= & -1,549+1,517 X_{1}+0,001 X_{2}+ \\
& 0,039 X_{3}+0,304 X_{4}
\end{aligned}
$$


Vol. 1 No. 2 (Mei 2021) (294-304)

Dari persamaan regresi linear berganda di atas dapat diketahui bahwa:

1) Nilai constant sebesar $-1,549$ menunjukkan bahwa tanpa adanya pengaruh dari variabel independen (kelengkapan produk, harga, promosi dan kepuasan pelanggan) terhadap loyalitas pelanggan maka nilai variabel dependen (loyalitas pelanggan) turun sebesar $-1,549$ satuan.

2) Nilai koefisien regresi kelengkapan produk $\left(\mathrm{X}_{1}\right)$ sebesar 1,517, artinya jika kelengkapan produk naik sebesar satu satuan, maka loyalitas pelanggan naik sebesar 1,517 untuk setiap satuannya, dengan asumsi variabel lain tidak mengalami perubahan atau konstan. Dengan nilai $t_{\text {hitung }}$ $10,343>\mathrm{t}_{\text {tabel }} 1,98$, dan nilai signifikan sebesar $0,000<0,05$.

3) Nilai koefisien regresi harga $\left(\mathrm{X}_{2}\right)$ sebesar 0,001 , artinya jika harga naik sebesar satu satuan, maka loyalitas pelanggan naik sebesar 0,001 untuk setiap satuannya, dengan asumsi variabel lain tidak mengalami perubahan atau konstan. Dengan nilai $\mathrm{t}_{\text {hitung }} 0,011<\mathrm{t}_{\text {tabel }} 1,98$, dan nilai signifikan sebesar $0,991>$ 0,05 .

4) Nilai koefisien regresi promosi $\left(\mathrm{X}_{3}\right)$ sebesar 0,039 , artinya jika promosi naik sebesar satu satuan, maka loyalitas pelanggan naik sebesar 0,039 untuk setiap satuannya, dengan asumsi variabel lain tidak mengalami perubahan atau konstan. Dengan nilai $\mathrm{t}_{\text {hitung }} 0,715<\mathrm{t}_{\text {tabel }} 1,98$, dan nilai signifikan sebesar $0,477>$ 0,05 .

5) Nilai koefisien regresi kepuasan pelanggan $\left(\mathrm{X}_{4}\right)$ sebesar 0,304, artinya jika kepuasan pelanggan naik sebesar satu satuan, maka loyalitas pelanggan naik sebesar 0,304 untuk setiap satuannya, dengan asumsi variabel lain tidak mengalami perubahan atau konstan. Dengan nilai $t_{\text {hitung }}$ $2,812>\mathrm{t}_{\text {tabel }} 1,98$, dan nilai signifikan sebesar $0,006<0,05$. 
Tabel 3. Hasil Uji F

\begin{tabular}{|c|c|c|c|c|c|c|}
\hline \multicolumn{2}{|c|}{ Model } & Sum of Squares & Df & Mean Square & $\mathrm{F}$ & Sig. \\
\hline \multirow{3}{*}{1} & Regression & 4173.586 & 4 & 1043.396 & 220.733 & $.000^{\mathrm{b}}$ \\
\hline & Residual & 430.154 & 91 & 4.727 & & \\
\hline & Total & 4603.740 & 95 & & & \\
\hline
\end{tabular}

Sumber: Olahan Data Primer Tahun 2021

Berdasarkan tabel diatas dapat dilihat nilai signifikansi dan $F_{\text {hitung }}$ dimana variabel kelengkapan produk, harga, promosi dan kepuasan pelanggan secara simultan atau bersama-sama berpengaruh signifikan terhadap variabel loyalitas pelanggan. Jika signifikansinya < 0,05 yaitu signifikansi tabel diatas adalah 0,000. Jika nilai $F_{\text {hitung }}>F_{\text {tabel }}$, maka variabel independen berpengaruh signifikan terhadap variabel dependen. Nilai $F_{\text {hitung }}$ pada tabel diatas adalah 220,733 $>\mathrm{F}_{\text {tabel }}$ 2,471. Dapat disimpulkan bahwa variabel independen (kelengkapan produk, harga, promosi dan kepuasan pelanggan) berpengaruh secara bersama-sama terhadap variabel dependen (loyalitas pelanggan).

1. Pengaruh Kelengkapan Produk Terhadap Loyalitas Pelanggan di Ramayana Padang

Berdasarkan hasil pengujian yang telah dilakukan diperoleh nilai koefisien regresi kelengkapan produk sebesar 1,517, artinya jika kelengkapan produk naik sebesar satu satuan, maka loyalitas pelanggan naik sebesar 1,517 untuk setiap satuannya, dengan asumsi variabel lain tidak mengalami perubahan atau konstan. Hal ini juga dibuktikan dengan hasil penelitian yang menyatakan bahwa nilai $t_{\text {hitung }}$ sebesar 10,343 $>\mathrm{t}_{\text {tabel }}$ sebesar 1,98 dengan nilai signifikan $0,000<0,05$. Hal ini menunjukkan bahwa terdapat pengaruh signifikan antara variabel kelengkapan produk $\left(\mathrm{X}_{1}\right)$ terhadap variabel loyalitas pelanggan (Y). Dengan demikian $\mathrm{H}_{0}$ ditolak dan $\mathrm{H}_{\mathrm{a}}$ diterima. Dalam hal ini kelengkapan produk mencakup tentang kelengkapan yang digunakan, variasi produk yang disediakan dan macam merk yanng dijual. Masalah kelengkapan produk ini sangat penting artinya bagi pelanggan, oleh karena itu perlu mendapatkan 
perhatian yang sungguh-sungguh dari perusahaan.

\section{Pengaruh Harga Terhadap Loyalitas Pelanggan di Ramayana Padang}

Berdasarkan hasil pengujian yang telah dilakukan diperoleh nilai koefisien regresi harga sebesar 0,001, artinya jika harga naik sebesar satu satuan, maka loyalitas pelanggan naik sebesar 0,001 untuk setiap satuannya, dengan asumsi variabel lain tidak mengalami perubahan atau konstan. Hal ini juga dibuktikan dengan hasil penelitian yang menyatakan bahwa nilai $t_{\text {hitung }}$ sebesar $0,011<\mathrm{t}_{\text {tabel }}$ sebesar 1,98 dengan nilai signifikan 0,991 >0,05. Hal ini menunjukkan bahwa tidak terdapat pengaruh signifikan antara variabel harga $\left(\mathrm{X}_{2}\right)$ terhadap variabel loyalitas pelanggan (Y). Dengan demikian $\mathrm{H}_{0}$ diterima dan $\mathrm{H}_{\mathrm{a}}$ ditolak. Pada umumnya harga menjadi salah satu penentu usaha sebagai tolak ukur bagi pelanggan untuk melakukan pembelian atau mengabaikannya. Akan tetapi dalam penelitian ini dapat disimpulkan bahwa harga tidak menjadi masalah bagi para pelanggan untuk membeli produk yang disediakan oleh Ramayana Padang. Harga tidak berpengaruh signifikan terhadap loyalitas pelanggan karena bergantung pada kesukaan responden terhadap produk yang dijual.
3. Pengaruh Promosi Terhadap Loyalitas Pelanggan di Ramayana Padang

Berdasarkan hasil pengujian yang telah dilakukan diperoleh nilai koefisien regresi promosi sebesar 0,039 , artinya jika harga naik sebesar satu satuan, maka loyalitas pelanggan naik sebesar 0,039 untuk setiap satuannya, dengan asumsi variabel lain tidak mengalami perubahan atau konstan. Hal ini juga dibuktikan dengan hasil penelitian yang menyatakan bahwa nilai $t_{\text {hitung }}$ sebesar $0,715<t_{\text {tabel }}$ sebesar 1,98 dengan nilai signifikan 0,477>0,05 Hal ini menunjukkan bahwa tidak terdapat pengaruh signifikan antara variabel promosi $\left(\mathrm{X}_{3}\right)$ terhadap variabel loyalitas pelanggan (Y). Dengan demikian $\mathrm{H}_{0}$ diterima dan $\mathrm{H}_{\mathrm{a}}$ ditolak. Tinggi rendahnya promosi yang dilakukan Ramayana Padang 
tidak akan mempengaruhi loyalitas pelanggan, karena pelanggan Ramayana merasa telah banyak menerima segala informasi dari Ramayana. Pelanggan merasa pihak Ramayana selalu memberikan kualitas terbaik sesuai dengan kenyataan serta selalu memahami apa yang menjadi keinginan dan kebutuhan pelanggan. Promosi di Ramayana memiliki jangka waktu yang lama sehingga pelanggan merasa tertarik serta diuntungkan dengan hal tersebut.

4. Pengaruh Kepuasan Pelanggan Terhadap Loyalitas Pelanggan di Ramayana Padang

Berdasarkan hasil pengujian yang telah dilakukan diperoleh nilai koefisien regresi kepuasan pelanggan sebesar 0,304, artinya jika kepuasan pelanggan naik sebesar satu satuan, maka loyalitas pelanggan naik sebesar 0,304 untuk setiap satuannya, dengan asumsi variabel lain tidak mengalami perubahan atau konstan. Hal ini juga dibuktikan dengan hasil penelitian yang menyatakan bahwa nilai thitung sebesar 2,812>ttabel sebesar 1,98 dengan nilai signifikan
$0,006<0,05$. Hal ini menunjukkan bahwa terdapat pengaruh signifikan antara variabel kepuasan pelanggan $\left(\mathrm{X}_{4}\right)$ terhadap variabel loyalitas pelanggan (Y). Dengan demikian $\mathrm{H}_{0}$ ditolak dan $\mathrm{H}_{\mathrm{a}}$ diterima. Kepuasan dapat dicapai apabila hasil yang diterima paling tidak harus sama dengan harapan konsumen atau bahkan melebihinya. Pada era kompetisi bisnis yang ketat seperti sekarang, kepuasan pelanggan merupakan hal yang paling utama.

\section{KESIMPULAN}

1. Terdapat pengaruh signifikan antara kelengkapan produk terhadap loyalitas pelanggan di Ramayana Padang. Dimana diperoleh nilai koefisien regresi sebesar 1,517 dan nilai $t_{\text {hitung }}$ sebesar $10,343>t_{\text {tabel }}$ sebesar 1,98 dengan nilai signifikan $0,000<0,05$ berarti $\mathrm{H}_{0}$ ditolak dan $\mathrm{H}_{\mathrm{a}}$ diterima.

2. Tidak terdapat pengaruh signifikan antara harga terhadap loyalitas pelanggan di Ramayana Padang. Dimana diperoleh nilai koefisien regresi sebesar 0,001 
dan nilai $t_{\text {hitung }}$ sebesar $0,011<$ $\mathrm{t}_{\text {tabel }}$ sebesar 1,98 dengan nilai signifikan $0,991>0,05$ berarti $\mathrm{H}_{0}$ diterima dan $\mathrm{H}_{\mathrm{a}}$ ditolak.

3. Tidak terdapat pengaruh signifikan antara promosi terhadap loyalitas pelanggan di Ramayana Padang. Dimana diperoleh nilai koefisien regresi sebesar 0,039 dan nilai $t_{\text {hitung }}$ sebesar $0,715<t_{\text {tabel }}$ sebesar 1,98 dengan nilai signifikan $0,477>$ 0,05 berarti $\mathrm{H}_{0}$ diterima dan $\mathrm{H}_{\mathrm{a}}$ ditolak.

4. Terdapat pengaruh signifikan antara kepuasan pelanggan terhadap loyalitas pelanggan di Ramayana Padang. Dimana diperoleh nilai koefisien regresi sebesar 0,304 dan nilai $t_{\text {hitung }}$ sebesar 2,812 $>t_{\text {tabel }}$ sebesar 1,98 dengan nilai signifikan $0,006<$ 0,05 berarti $\mathrm{H}_{0}$ ditolak dan $\mathrm{H}_{\mathrm{a}}$ diterima.

5. Kelengkapan produk, harga, promosi dan kepuasan pelanggan berpengaruh signifikan secara bersama-sama terhadap loyalitas pelanggan. Dimana diperoleh nilai $F_{\text {hitung }}$ sebesar 220,733 > $\mathrm{F}_{\text {tabel }}$ sebesar 2,47 dengan nilai signifikan
$0,000<0,05$ dan dapat menjadi prediktor yang baik dari loyalitas pelanggan.

\section{DAFTAR PUSTAKA}

Amanah, D. (2018). 'Pengaruh Promosi dan Brand Image (Citra Produk) Terhadap Loyalitas Pembelian', Journal of Chemical Information And Modeling, 53(9), Pp. 1689-1699. Doi: 10.1017/Cbo9781107415324. 004.

Herlina (2018). 'Analisis Pengaruh Harga dan Kelengkapan Produk Terhadap Keputusan Pembelian Serta Dampaknya Pada Kepuasan Konsumen', Analisis Pengaruh Harga dan Kelengkapan Produk Terhadap Keputusan Pembelian Serta Dampaknya Pada Kepuasan Konsumen, 13(2).

Marlina. (2018). 'Pengaruh Kualitas Pelayanan, Promosi, Harga dan Kualitas Produk Terhadap Loyalitas Pelanggan Lipstik Wardah Di Kota Padang (Studi Kasus Toko Alfalah Pasar Raya Padang)', Ilmiah Stkip.

Normasari, S. (2013). 'Pengaruh Kualitas Pelayanan Terhadap Kepuasan Pelanggan, Citra Perusahaan dan Loyalitas Pelanggan Survei Padatamu Pelanggan Yang Menginap Di Hotel Pelangi Malang', 
Jurnal Administrasi Bisnis S1 Universitas Brawijaya, 6(2), Pp. 1-9.

Pongoh, M. E. (2013). 'Kualitas Pelayanan, Kualitas Produk dan Harga Pengaruhnya Terhadap Loyalitas Pelanggan Kartu As Telkomsel Di Kota Manado', Jurnal Emba, 1(4), Pp. 1-5. Doi: $\quad$ 10.1007/S13398-0140173-7.2.

Sari, M. K. (2012). 'Pengaruh Penerapan Experiential Marketing Terhadap Loyalitas Konsumen Kartu Pra Bayar Simpati Telkomsel Mareta Kemala Sari', 1(1). http://dx.doi.org/10.22202/ec onomica.2012.v1.i1.108

Soraya, I. (2015). 'Pengaruh Promosi dan Ekuitas Merek Terhadap Loyalitas Konsumen Cipaganti Travel', Komunikasi, Vi(September), Pp. 11-23.
Sugiyono. (2012). Metode Penelitian Kuantitatif Kualitatif dan $R$ \& D. Edited By Alfabeta. Bandung.

Suparmi And Handhoko, K. (2018). 'Pengaruh Kepuasan, Kepercayaan dan Komitmen Terhadap Loyalitas Pelanggan Pada Pt. Yodya Karya (Persero) Cabang Utama Semarang', Jurnal Ilmiah Untag Semarang, 7(1), $P p$. $102-$ 112.AvailableAt:http://Jurnal .Untagsmg.Ac.Id/Index.Php/S a/Article/View/703/6.

Utami, H. Y. (2014). 'Pengaruh Tangible , Empathy , Reliability , Responsiveness dan Assurance Terhadap Loyalitas Pelanggan Berbelanja Pada Toko Tita Di Lubuk Buaya Kota Padang Hayu Yolanda Utami', 3(1).

http://dx.doi.org/10.22202.economic a.2014.v3.i1.237. 